\title{
On the Support of the Oilfield Service in the Russian Federation
}

\author{
O. V. Zhdaneev ${ }^{a, *}$ and P. Yu. Sorokin ${ }^{a}$ \\ ${ }^{a}$ Ministry of Energy of the Russian Federation, Moscow, 107996 Russia \\ *e-mail: zhdaneev@rosenergo.gov.ru \\ Received March 1, 2021; revised March 16, 2021; accepted April 8, 2021
}

\begin{abstract}
This article makes use of financial-economic modeling to study the measures of providing necessary support to Russian oilfield service companies due to a reduction in the amount of orders on the part of oil and gas companies because of the slowdown in the demand for energy inputs as a result of restrictions related to the COVID-19 pandemic. The global practices of drilling uncompleted wells are analyzed; a brief review of the current market situation is provided. The need for taking system-level steps to support the industry and maintaining the key competences and share of Russian companies in the market is shown.
\end{abstract}

Keywords: oilfield services, government support, COVID-19, financial modeling, import phaseout, drilled but uncompleted wells, taxes

DOI: $10.1134 / \mathrm{S} 1075700721050142$

Introduction. On June 9, 2020 the Government of the Russian Federation issued Directive 1523-r to adopt Russia's Energy Strategy for the period up to 2035 (hereafter referred to as Energy Strategy-2035). This document sets the main goals for the national fuel-and-energy complex. It is expected that by 2035 the amount of oil and gas condensate production will range from 490 to $555 \mathrm{mln}$ tons.

In April 2020 the unparalleled provisions made to limit the propagation of COVID-19 resulted in a major cutback in the demand for oil, which caused the respective drop in the oil prices [1]. To stabilize the market situation, the members of the OPEC + Pact agreed upon the new parameters of the deal to cut the production of oil [2]. According to the International Energy Agency, the limitations introduced due to the pandemic cut the global daily oil demand in 2020 to 91.28 millions barrels [3]. Moreover, the reduction in the oil output under the OPEC+ Pact was all-time high (about 23\% of the levels of 2019). The greatest commitments to curtailing the oil production were undertaken by Russia and Saudi Arabia. As of November 2020, the trade settlement level as estimated by the Monitoring Committee was 101\% [4].

At year-end 2020 the output of oil and gas condensate in Russia was 512.7 million tons ( $-8.6 \%$ YoY). The reduction was caused mainly by the plug and abandonment of wells at old fields, which required making additional efforts to recover the production. It should be noted that Russia as an exporter of energy resources has no extra large scale capacity. The amount of oil treated in this country is more than twice as high as the domestic demand for oil. According to Energy Strategy-2035 the available infrastruc- ture will be expanded and new capital-intensive projects implemented; each of these, however, will require a lot of time for construction.

At the same time, the drop in the revenue of Russian oil companies made the major players holding more than $80 \%$ of the Russian market declare that they would reduce their investment programs to $20 \%$ of the previously announced target levels [5]. The possibility of achieving the goals set forth in Energy Strategy-2035 is compromised by the plans of reducing capital expenses. These plans directly affect related sectors and, first of all, oilfield service companies and oil-and-gas machine building enterprises.

Since 2005 Russia's market for oilfield services rose by $10-12 \%$ YoY on average. The exception to this tendency was 2009 when the market dropped by $1.8 \%$. The share of this market occupied by the domestic enterprises for the past decade is as high as 70\% [6].

According to the Central Control Administration of the Fuel and Energy Complex (CCA FEC), in 2009-2019 the exploitation drilling would rise by $8 \%$ on average and the total driftage was 27.4 million $\mathrm{m}$. After the drop by 5\% in 2014, in 2015 the exploitation drilling rose by $9 \%$; however, despite the negative oil price fluctuations from 2014 to 2017, that period witnessed a steady growth of exploitation drilling driftage. As usual, the leading region in exploitation drilling has been the Khanty-Mansi Autonomous Okrug; it ensured about $80 \%$ of increment annually by increasing the construction of horizontal wells. In 2020 the total metreage of the horizontal well drilling in the region went up by $20 \%$ on average as compared with 2019 and reached about $50 \%$ of the total volume of drilling in Russia [7]. 


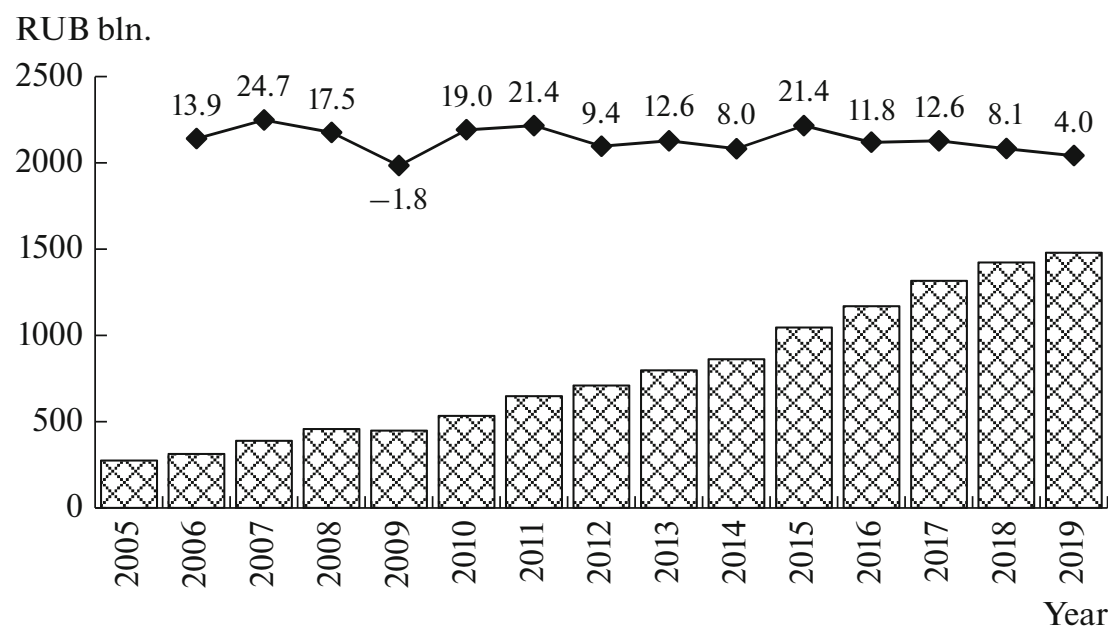

Fig. 1. Market for oilfield services in 2010-19: $\bigcirc$ annual aggregate volume of the oil-bearing market in Russia; $-\longrightarrow$ YoY increment $(\%)$.

Russia has also started to actively develop programs of import substitution of oil and gas equipment and design essentially new drilling and production technologies (including for disruptive kinds of hard-toextract mineral deposits). According to the information from corporate import phaseout plans of public joint-stock companies for 2019, the share of Russianmade equipment in the total amount of unconventional reservoirs bought back then was $86 \%$ on average. However, there is a substantial dependence (from 80 to $100 \%$ ) on the high-tech imported equipment that is requried for the Arctic and unconventioal reservoirs development [8].

Review of the Russian market for oilfield services. The market for oilfield services covers not only well drilling and development services but also seismic and geophysical wireline logging, building of relevant infrastructure, and manufacture of the equipment for pursuing these efforts. Oilfield service companies have historically been the development drivers of oil-andgas industry. In January 2020 Russia had more than 300 oilfield service companies with more than 300,000 employees in total [9]. In 2019 the overall estimated volume of the market for oilfield services and drilling was 1.5 trillion a and 756 million roubles, respectively.

In 2020 the world market for oilfield services continued to stagnate due to the limitations caused by the pandemic. The stagnation began way back in 2014 (Fig. 1). First of all, oilfield service companies are geared to orders from licensed area operators that cut their capital expenses due to dropping demand and commodity prices, postpone new extraction projects, and cut back on $\mathrm{R} \& \mathrm{D}$ programs.

According to the Baker Hughes company, in May 2020 the number of operated drilling rigs around the world reached its minimum since April 1999. According to the estimate by the International Energy Agency
(IEA), in 2020 the global capital expenses by oil and gas companies decreased by $32 \%$ YoY to 335 billion dollars [10].

The 2020 decline in the oil market is a threat to the positive trend in the development of the oilfield service industry. The shrinking in the volume of the market for oilfield services will also affect the related industries, such as machine building, steelmaking, manufacture of general mechanical rubber products, and others. This can cause mass-scale job cuts and violate the financial stability of enterprises. The most vulnerable businesses are Russian small-scale enterprises and oilfield services companies not included in vertically integrated oil companies (VIOC).

According to the results of the survey conducted by the Ministry of Energy of Russia in 2020, at the end of 2019 the oilfield service companies signed contracts for execution in Q1 and Q2 of 2020, which allowed mitigating the drop in the proceeds for these quarters (-5\% per six months). In 2020 the YoY proceeds of oilfield service companies were expected to drop by 7$10 \%$. However, as compared with 2019 , the size of orders by small and medium businesses could shrink by more than $50 \%$. It is expected that in 2021 the drop across the industry in general will be $20 \%$ (to 1.1 trillion roubles).

In 2020 oilfield service companies increased their capital expenses to 137 billion roubles ( $+5 \%$ YoY), which was due to the upgrading of outdated equipment funds, planned already in 2019. In 2021 the investments across the industry are expected to drop to 112 billion roubles, which can impair the scientific and engineering progress of oil-and-gas industry and create risks for developing new reservoirs, e.g. hard to recover reserves (HRR), reservoirs in the remote regions and small provinces. 
In 2020 the companies planned to dismiss up to $7 \%$, and in 2021 they plan to dismiss up to $6 \%$ of their employees. The job cuts by about 35,000 people will cause negative effects in both, the industry in general (lack of high-skilled workforce) and the regional economies. If the situation aggravates, the companies can cut up to $50 \%$ of their employees; however, this will actually mean the loss of key competences for many years.

Currently, Russia 1200 drilling rigs with a load capacity of 180 to $750 \mathrm{t}$, which can be used for deephole exploitation and extension drilling of oil and gas wells, and about 600 drilling rigs of 125 to $170 \mathrm{t}$ in load capacity, which can be used for for production and exploration drilling and for sidetracking.

For the last five years till the spring 2020 most of them had been in operation non stop.In 2019 there were at least 1700 registered drilling rigs in operation with a load capacity of 125 to $750 \mathrm{t}$. In the second half of 2020 the number of active drilling rigs decreased by $10 \%$ to reach 1520 units. It is expected that the next 15 years will see $45 \%$ of Russia's fleet of these rigs written off due to complete wear [11]. In Russia the number of annually produced drilling rigs reaches 25 to 50 units. About $20 \%$ of the decomissioned rigs would be possible to replace with new ones by the slowdown of drilling acrivities. This will be impacted by the existing rate of return (about 6-10\%) and manufacturing capacity. As a result, we would face the outdating fleet of drilling equipment and inability to overcome the technological gaps.

Within this context, the share of international drilling companies in the Russian drilling market could increase from 30 to $70 \%$ by 2030 . It would be worth mentioning that the Ministry of Industry and Trade of the Russian Federation has adopted a new program of subsidizing the purchase of new Russian-made drilling rigs. A subsidy can reach up to $20 \%$ of the rig cost, which is a potent measure of support. All in all, about 600 million roubles were planned for distribution under the program in 2020; however, that amount sufficed for buying only 4-12 drilling rigs, depending on the load capacity, which was clearly too low to make substantial changes to the situation.

Considering various types of customer-contractor relations, affiliated drilling companies remain the dominant force in the market. This group with various organizational and legal business frameworks includes the drilling rigs of PJSC Surgutneftegaz, LLC RN Burenie (affiliated undertaking of Rosneft), LLC Megion Department for Drilling Works, LLC Megion Geology, and LLC Baikit Oil and Gas Exploratory Company (affiliated undertaking of PJSC SlavneftMegionneftegaz), LLC INK Service (affiliated undertaking of LLC Irkutsk Oil Company), and independent contractors most of the business deals of which $(>75 \%)$ are related to a single customer.
It is highly probable that the shortage in orders will mostly fall on small to medium-size drilling companies. They are expected to suffer from a serious weakening of thier financial position, which can lead to the buyout of their assets with the subsequent consolidation of the drilling market. At the same time, the global experience of the oil industry shows that small and medium companies play a major role in promoting and developing innovations for these businesses are better ready for assuming high business risks due to the adoption of new technologies.

Since 2014 the devaluation of rouble has been one of the factors of the increased stability of Russia's oil industry. As estimated by Rystad Energy, in 2020 the devaluation would cut the operating costs of Russian by about 5 billion dollars. At the same time, the subsequent sale of this resource is limited by the current priorities oriented at the domestic demand and creating high-margin derived domestic products.

To support the market for oilfield services and achieve the goals set forth in Energy Strategy-2035, the Russian government is discussing the opportunities for implementing the Drilling but Uncompleted (DUC) Well program (hereafter referred to as the Program) in 2021-25; this Program provides for the potential investments of up to 400 billion roubles in drilling about 3000 DUC wells.

Review of Global DUC Well Drilling Practices. The drilling of DUC wells has been practiced in many countries since the first years of the oil and gas industry. DUC wells have been built in the United States and China since 2014 for developing unconventional reserves in post-crisis periods and allowed waiting until the oil price becomes optimal for development. According to the evidence from global practice, DUC wells are those that have not been put in operation for six months after the end of drilling works [12].

After the 2014 crisis a lot of US-based oil companies paid their attention to drilled but uncompleted wells as part of their strategy of adapting to new market conditions. The sharp rise in the shale oil production in the United States from two to six million barrels in $2007-18$ is usually related to the drilling of DUC wells, their rational commissioning and the scientific and engineering progress in oilfield services. According to the Energy Information Agency (EIA), at the end of 2020 there were about 8000 uncompleted wells in the United States, that is, their highest number in modern history. It should be noted that, according to ExxonMobil, this figure can be understated by 2000 wells because some of the market players follow a new policy of not disclosing the data on their high-risk assets. About a half of the 8000 wells are situated in the Perm basin that covers parts of Texas and New-Mexico and is currently the region of the most active drilling works around the world (since 2014 the number of wells in the region has went up by more than $500 \%$ [13]). The insufficient number of available well completion and 
hydraulic fracturing crews and the insufficient throughput of pipelines also affect the increase in the number of wells and make subsurface users launch, first of all, the most profitable of those. That said, a lot operators continue drilling the minimal number of wells for retaining the leasehold of licensed areas. As predicted by Rystad Energy, the number of DUC wells in the United States will increase by $10 \%$ owing to public companies and by $16 \%$ owing to private operators. According to several studies, these wells exhibit a negative economic efficiency during long downtime periods (their profitability ranges from 15 to 50\%) [14].

In the current economic situation some of the stakeholders are displeased with the drilling of uncompleted wells in the United States because, in the long-run, the oil prices are expected to significantly rise only on condition that the countries of Asia and Africa experience a rampant economic development and their actual oil demands significantly exceed the predicted growth rates [15]. The breakeven price for most of such wells ranges from 50-60 dollars per barrel. There are more and more cases when banks refuse to provide loans to oil companies, which has partially resulted in more than 250 bankruptcy notices. However, Trump's administration sided with oil and oilfield service companies to retain the share of the United States in the global oil market and tried obliging the banks to provide loans despite the market situation and also allocate support the industry by subsidizing.

In China similar uncompleted well building programs are implemented to increase the production of shale gas. Chinese companies have announced these programs since 2016 but there are no exact data on the number of drilled wells. In China the gas production rose by $70 \%$ for the past decade; as of 2020 , however, more than a half of the gas consumed in the country was imported [16]. The national government is going to put in use large has reserves that have increased by $100 \%$ in the past three years (up to six trillion cubic meters). In the current economic situation, however, these reserves are noncommercial and the operators drill DUC wells rather for testing new technologies that cut the total development costs. Nevertheless, Chinese companies gradually place on production (with 80 to 100 wells a year) fields with earlier drilled uncompleted wells. In 2020 these companies increased the annual production level by 30 billion cubic meters, that is, by $1.1 \%$ YoY and $+20 \%$ as compared with the level achieved in 2015.

It should be noted that since the early 1990s Chinese and US-based oilfield service companies have made efforts for capturing global regional markets. Nowadays, the stability of these companies is maintained by means of assets in other countries, which is currently impossible for Russian companies.

DUC Well Program. In Russia this practice has not been used en masse. However, there are certain projects, such as Chayandinskoe and Kovyktinskoe fields the gas from which will be pumped to the Power of Siberia export pipeline. This development plan was chosen by PJSC Gazprom from the standpoint of economic expediency and to meet the conditions for transporting a required amount of gas to China in short timeframes from the date of putting the pipeline in operation.

Despite the fact that certain companies did have respective financial capacities in the past, nowadays, the operators cannot support oilfield service companies by means of proprietary funds alone. According to the poll among the companies, in 2021 they expect their proceeds and EBIT to decrease by 20 to $45 \%$ and by 30 to $55 \%$ YoY, respectively; however, the WACC of the top companies will still be around $13 \%$, which indicates that the companies do not want and often have no opportunity for taking new loans.

The DUC Well program elaborated as part of fulfilling the order by the President of Russia to create the conditions for establishing the fund of DUC wells to support the domestic market for oilfield services takes into account the world practices of drilling uncompleted wells and subsequently putting them in operation. The operators are going to drill wells in fields with nonshale resources the development of which was planned for 2020-22 but was postponed due to the decline of production as part of the OPEC+ Pact. In addition, the experience of the United States was considered, where in areas with a high well density index the combination of extended production and fracturing stages with a lot of perforation clusters could lead to a shortage of reserves available for extraction from uncompleted wells. Therefore, the operators chose optimal sites for subsequent drilling.

The Program's procedure involves creating a special-purpose vehicle (SPV) that will include VIOCs and a bank syndicate with respective participation interests of 2 and $98 \%$. The SPV will enter into general contractor agreements with a reservoir license holder to build wells and development facilities thereunder by means of loan production. In this case, the VIOC will be responsible for the technical aspects of managing the project, including order procurement and processing, drilling control, and supervision. When the works are finished, the new objects will remain on the books of the SPV until the reservoir license holder fulfills the covenants, takes over the constructed objects from the SPV, makes the payment, puts the objects in operation, and registers the right of ownership. The SPV is needed for separating the wells built under the Program from other wells and also for segregating cash. In addition, the Program's option without SPV is being discussed for those companies that are ready to take the debt under this Program on their books. Another option under discussion is to expand the Program by drilling gas wells due to the price drop caused by the occupancy of gas storage facilities in Europe and Asia. 


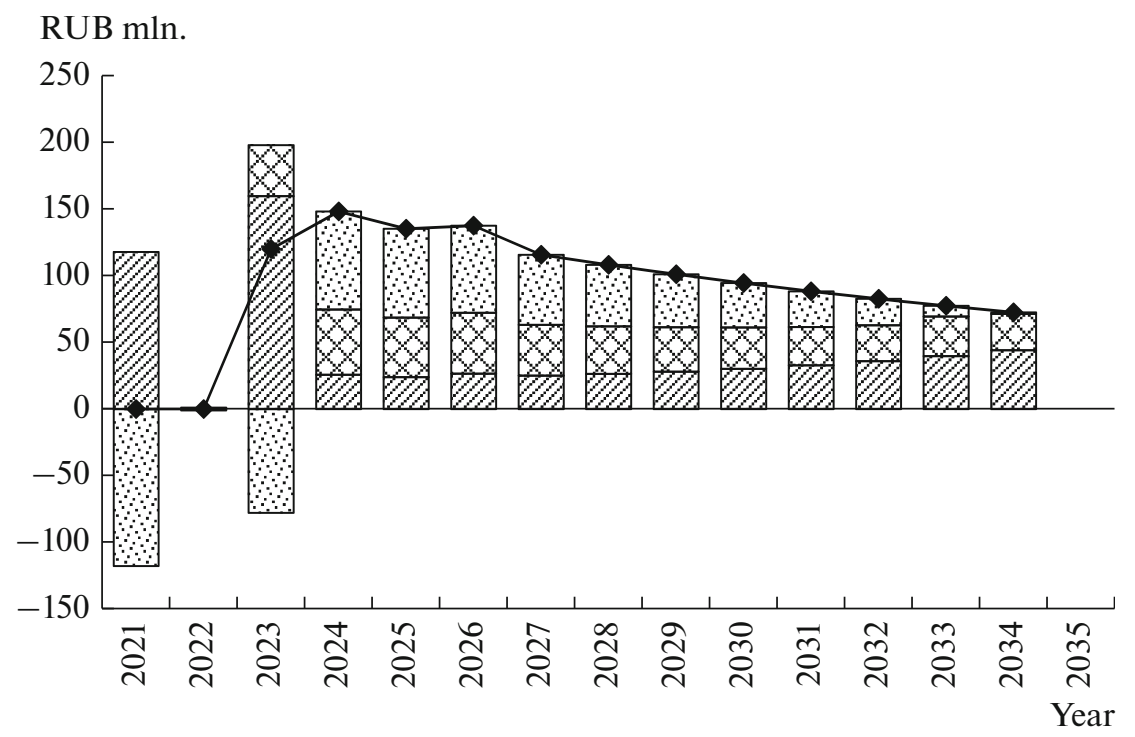

Fig. 2. Money flow for the basic well planned for construction as part of the Uncompleted Well Program: 0 money flow; $\mathrm{Q}$ taxes; $\square$ expenses; $\sim$ earnings.

The possibility of providing an investment tax credit at the moment of registering the wells on the books of VIOCs is under discussion as well. The investment tax credit will be valid and apply for a specified number of years since January 1, 2022 to those tax payers the aggregate mineral resources extraction tax base of which with respect to oil in the tax periods prior to 2019 was more than one million tons. The potential investment tax credit is equal to two thirds of the key interest rate set by the Bank of Russia for the SPV's aggregate expenses on building the objects or DUC of the reservoir license holder's expenses on servicing credit resources.

The respective federal bill has been prepared, according to which the Tax Code is expanded by adding clause 286.2 Investment Tax Credit on Creating the Reserve of New Objects Needed for Exploring and Extracting Hydrocarbon Materials. The bill is currently under approval by interested relevant ministries.

The discounted cash flow model for a basic well was drawn for the purposes of economic design. The DUC design, production profile, and the relevant cost structure (1.6 mln dollars) were estimated in cooperation with the sectoral community. The macroeconomic parameters were based on the recent forecast by the Ministry of Economic Development of Russia [17]. The results of calculating the supposed output from an individual well and the prospective well construction and commissioning schedule were used to build the mathematical model of the whole program (Fig. 2).

The Program will allow providing oilfield service companies with orders from Q1 of 2021 until April 2022 and service up to 3000 wells.
In addition, it is necessary to consider the potential change in the energy balance pattern due to energy transition. The transition period can cut the added value of the FEC by $25 \%$ and the added value of the sectors ensuring its support by another two to three percent. Thus the support to the industry should be provided as soon as now so that it has enough financial resources for redesigning in the new market conditions and turning more competitive.

Rystad Energy expects that in 2023-25 the global oil supply will drop due to the reduction in the investment cuts to the FEC in 2020-22. In 2020 the world's oil companies cut their investments by 170 billion dollars YoY. An extended period of low investments can reduce the global oil production by five million barrels a day (mbd). If the Program is implemented, the putting of DUC wells in operation will allow Russia to rapidly increase its oil output by $0.2 \mathrm{mbd}$ and supply to the market about $0.5 \mathrm{mbd}$ of extra crude oil for the respective period.

The total potential tax credit for $2022-25$ will be a little higher than 30 billion roubles. At the same time, it will be fully reimbursed by the tax proceeds from the new wells which will be put into operation in 2023-24 (Fig. 3). It is estimated that the national budget would gather around 1.5 trln.rubles of additional income during the DUC program and the additional investments from the operators would be around $300 \mathrm{bln}$. rubles. It is necessary to give the tax credit to VIOCs as the amount of SPV taxes would not be enough to reimburse the related costs.

The adoption of the Program will require making changes in the regulation of well building for adopting the term drilled but uncompleted well in the legal framework of Russia. This initiative can create a new list of 


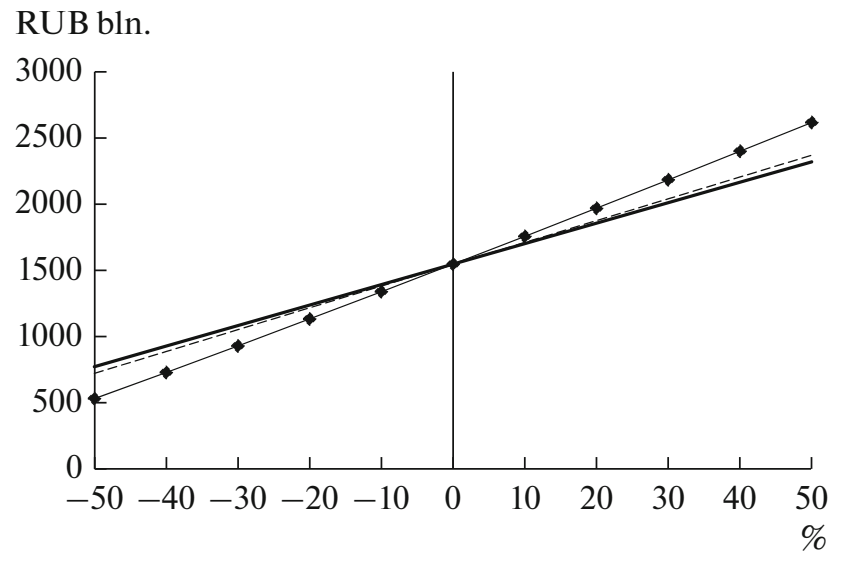

Fig. 3. Analysis of the oil prices, currency exchange rates, and government revenue for sensitivity to the change in the amount of subsidies as part of the Uncompleted Well Program: $\_$USD/RUB exchange rate; — Urals oil price; --- amount of subsidies.

services oilfield service companies will provide in future for developing unconventional oil and gas reserves; in particular, these services include creating small innovative businesses for providing specialized hi-tech services with Russian-made equipment.

According to the global practice of drilling uncompleted wells, the optimal period of placing them on production ranges from two to three years. Then it will be necessary to perform expensive well repairs, which will negatively affect the project's economic efficiency [18]. Different operators use different well building methods. For example, some of the operators do not plan to reach the target horizon during horizontal well building, and the DUC wells will end up with the setting and fixing of a production liner. The operators will complete the drilling and build the horizontal sections after buying out the wells from the SPV and then put them in operation (Fig. 4). The building of direc- tional wells will involve tapping the productive interval and floating and fixing the production string. However, the development phase (perforation, etc.) will be postponed until commissioning. With this approach (as was seen in the US) there is a large risk of substantial fluctuation of production volume. This is due to the fact that in the traditional case there is always some adjustment made based on the drilling and logging results from the closely placed wells. When DUC wells are build within the producing reservoirs this risk is rather small. However, there may be cases when reserves at the edges are not confirmed.

Another option considered by the operators is to mothball the wells after perforation and explosive operations (PEOs). This differs from the originally considered procedure under which the SPV could accept only economic wells on its books. According to the valuation of inventory, the oil price below 40 dollars per barrel makes uneconomic more than $70 \%$ of the reserves in West Siberia [19]). These risks are fully assumed by the VIOC as the technical party to the project's management.

First of all, the program is intended to support the oilfield service sector. As of the end of 2019, the total debt burden and lease liabilities of Russia's oilfield service companies were about 350 billion and 125 billion roubles, respectively. The implementation of the program will ensure that in 2021 the demand for oilfield services will be at least $80 \%$ of the rates achieved in 2019, including due to placing the given DUC wells on production (Fig. 5).

The program would positively impact the development of the disrupt technologies as the companies will not cut their R\&D expenses. In particular, the companies planned to invest two billion roubles in developing digital platform solutions which are also a priority under Energy Strategy-2035. It is worth highlighting the development of the highly automated drilling rigs for the onshore and offshore applications. The lack of

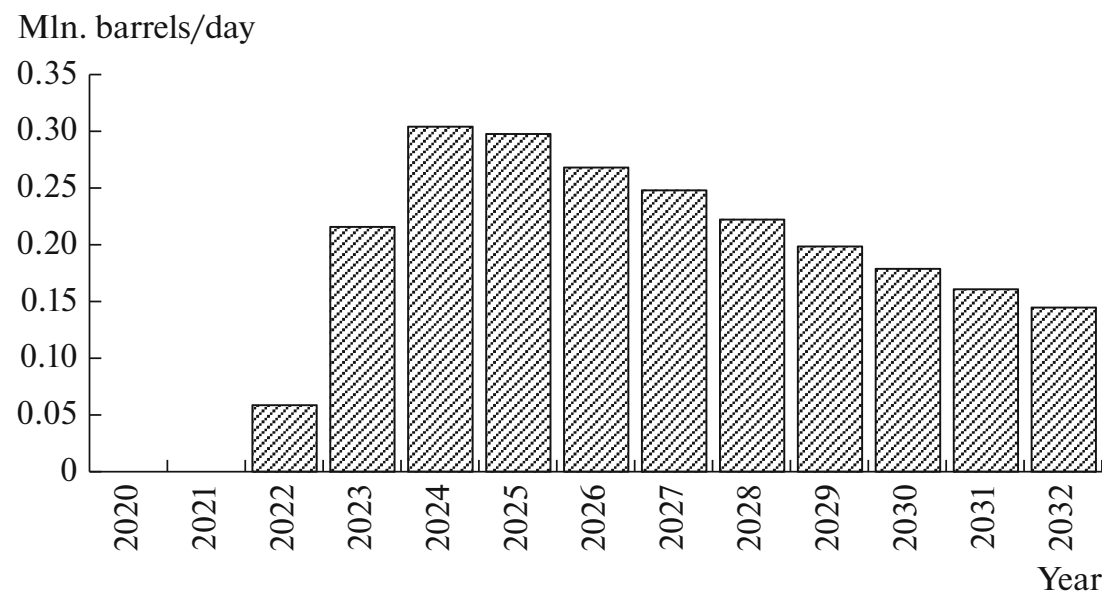

Fig. 4. Oil production schedule under the Uncompleted Well Program. 


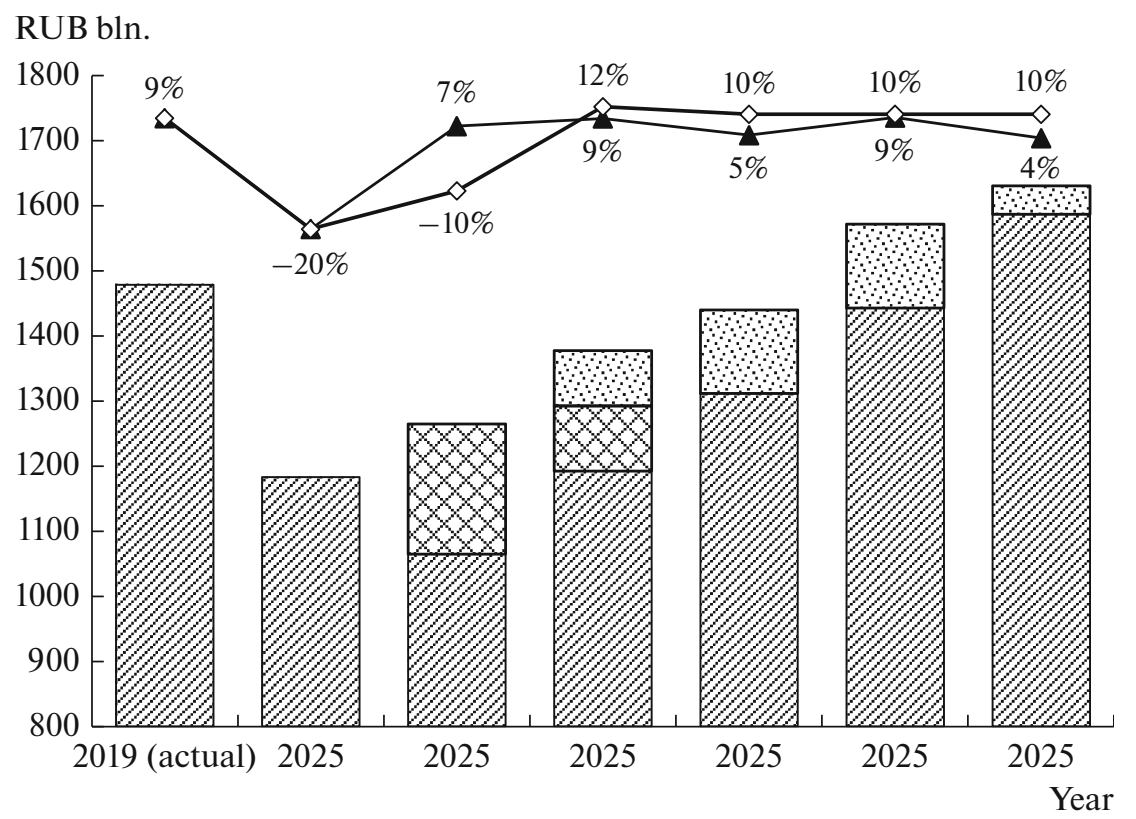

Fig. 5. Predicted volume of the market for oilfield services in 2020-25:

additional effect of the Program (putting wells in operation);

$\triangle$ the Program's volume;

$\triangle$ market volume w/o the Program;

- market behavior with the Program (CAGR), \%;

$\checkmark$ market behavior w/o the Program (CAGR).

support will negatively impact the infant market for the specialized software development. This sector's revenue in 2019 was around 2 bln roubbles and has outstanding export potential. These new products could be piloted during the DUC program execution.

It could take up to 2 to 5 years to reach the precrisis level of the oilfield service market even with the deployment of the DUC program. However, with the program in place, the Russian companies will preserve their key competences and market share.

\section{CONCLUSION}

The DUC Well program is a fair tradeoff between the risks of its implementation and the potential benefits to all of the participants from its execution. The complicated economic situation in the oil and gas industry due to the crisis caused by the pandemic makes it socially important for the government to support to the oilfield service industry with its more than 500 thousand employees.

It should be noted that the tax deduction equal to two-thirds of the key interest rate set by the Bank of Russia (4.25\% as of the time this article was written) will not make the oil and gas companies richer because the residual loan interest will counterbalance the dif- ference; however, the oilfield service companies will have extra funds for order placement and processing.

In Russia the future of the market for oilfield services depends not only on adopting the Program but also on the further activities of the oilfield service companies. If there is no scientific and engineering progress in this sector, the share of foreign companies in the market will go up due to the rising demand for hi-tech pipeline services. According to the priorities fixed in Energy Strategy-2035, the government will surely support Russian companies in their R\&D efforts to develop new disrupt equipment and technologies.

\section{REFERENCES}

1. M. Finley, J. Krane, and K. B. Kenneth Medlock III, Price War and Pandemic: The Oil Market Reaction, Apr. 1 (2020). https://www.bakerinstitute.org/media/files/b24814f4/ces-pub-oilpricecrash-040620.pdf.

2. 15-th OPEC and non-OPEC Ministers Meeting (ONOMM), Production Adjustments Table, Apr. 1 (2021). https://www.opec.org/opec-web/static_files_project/ media/downloads/15-th\%20ONOMM\%20-\%20Production\%20adjustments\%20table.pdf.

3. International Energy Agency, Oil 2020, Mar. 1 (2020). https://www.iea.org/reports/oil-2020. 
4. Ghaddar Ahmad, OPEC+ oil output cut compliance at $101 \%$ in November -sources (2020). https://www.reuters.com/article/oil-opec-int-idUSKBN2941DP.

5. A. S. Pyatin, "Putin personally met with Sechin," Forbes May 12 (2020). https://www.forbes.ru/newsroom/obshchestvo/400355-putin-lichno-vstretilsya-ssechinym?utm_source=yxnews\&utm_medium=desktop.

6. Problems of the Technical Policy of the Fuel and Energy Complex of the Russian Federation, Ed. by O. V. Zhdaneev (Nauka, Moscow, 2020) [in Russian]. https://doi.org/10.7868/9785020408241

7. D. S. Zavalov, P. V. Matvievskii, A. I. Shved, A. G. Zuev, V. V. Pimonov, and A. V. Yudel'son, "Commissioning of new oil wells," TEK Ross., No. 1 (2020). https://www.cdu.ru/catalog/zhurnal_tek_rossii/.

8. O. V. Zhdaneev and V. S. Chuboksarov, "Technical policy of the oil and gas industry in Russia: Tasks and priorities," Energ. Polit., No. 5, 76-91 (2020). https://energypolicy.ru/?p=4026\&fbclid=IwAR29B8i7JVpgReVNv6vDXB5qTIS6B939GKPh584QTE0-SdMNSfloX920rw.

9. S. V. Rudnitskii, "Implementation of the government initiative to form the uncompleted well stock is postponed," Burenie Neft', Dec. 7 (2020). https://burneft.ru/main/news/35225.

10. International Energy Agency, Oil 2020, Mar. 1 (2020). https://www.iea.org/reports/oil-2020.

11. O. V. Zhdaneev and K. N. Frolov, "On the priority directions of development of drilling technologies in Russia,” Neft. Khoz., No. 5, 42-48 (2020). https://doi.org/10.24887/0028-2448-2020-5-42-48

12. K. Srinivasan, J. Krishnamurthy, and P. Kaufman, "The DUC hunt: Concerns and clarifications for drilled uncompleted wells. What to expect?," in $S P E$
Western Regional Meeting (Bakersfield, CA, 2017). https://doi.org/10.2118/185753-MS

13. K. Srinivasan, J. Krishnamurthy, and P. Kaufman, "Concerns and clarifications for drilled uncompleted (DUC) wells in the Williston Basin," SPE Res. Eval. Eng. 22 (1), 190-202 (2018). https://doi.org/10.2118/185753-PA

14. K. Barani, "Uncompleted wells in the US: A time bomb for the oil market?," Investing Apr. 16 (2019). https://ru.investing.com/analysis/article-200252971.

15. A. Yu. Kolpakov, "Potential trajectories of oil price dynamics," Stud. Russ. Econ. Dev. 30, 384-392 (2019). https://doi.org/10.1134/S1075700719040075

16. A. A. Makarov, "Technological progress opportunities in the energy sector of Russia," Stud. Russ. Econ. Dev. 31, 52-63 (2020). https://doi.org/10.1134/S1075700720010086

17. Forecast of the Socio-Economic Development of the Russian Federation for 2021 and for the 2022-2023 Planning Period of September 26, 2020. https://www.economy.gov.ru/material/directions/makroec/prognozy_socialno_Ekon._razvitiya/prognoz_socialno_Ekon._razvitiya_rf_na_2021_god_i_na_planovyy_ period_2022_i_2023_godov.html.

18. R. L. Kleinberg, S. Paltsev, C. K. E. Ebinger, D. A. Hobbs, and T. Boersma, "Tight oil market dynamics: Benchmarks, breakeven points, and inelasticities," Energy Econ. 70, 70-83 (2018).

19. G. V. Vygon, "Inventory of reserves: From state expertise to national audit," Vygon Consulting. https://vygon.consulting/upload/iblock/ce8/20191105_ngv_vygon.pdf.

Translated by S. Kuznetsov 